\title{
Sweet and Bitter: Trajectories of Sugar Cane Investments in Northern Luzon, the Philippines, and Aceh, Indonesia, 2006-13
}

\author{
Mohamad Shohibuddin, Maria Lisa Alano, and Gerben Nooteboom
}

\begin{abstract}
This chapter aims to understand the complex process of investment and land deal making through the in-depth study of three cases of sugar cane investment in the Philippines and Indonesia. It focuses on three different trajectories of sugar cane schemes - one in northern Luzon, the Philippines, and two in Aceh, Indonesia. By means of a processual approach, the chapter identifies critical junctures-defined as crucial moments of dealmaking and interactions in which relations among actors are renegotiated - at which the investments took decisive turns. These are the collaboration of investors and bureaucratic cooperation between different levels of government; control of the development agenda; land deal making and control over land; control of labour; and curbing resistance. The chapter thus shows that investments in sugar cane and bioethanol-which often involve land deals - usually turn out differently than originally envisaged. Implementation problems arise due to the competing strategies and interests of investors, government departments, workers, landowners, and brokers, and due to specific historical and institutional constellations. Therefore, it can be argued that the implementation of investment schemes cannot simply be understood as the implementation of a contract or an already-planned programme; it should rather be understood as a constant process of negotiation and adaptation. In such a context, the identification of critical junctures is crucial for the conduct of monitoring activities and the adoption of adaptive policies during land deal processes.
\end{abstract}

This paper is based on the PhD fieldwork of Maria Lisa Alano (in northern Luzon) and Mohamad Shohibuddin (in Aceh), carried out in 2012-13. The authors are members of a research project on (trans)national land investments in Indonesia and the Philippines, funded by the Netherlands Organisation for Scientific Research (Nwo) wотro Science for Global Development programme.

(C) Graduate Institute of International and Development Studies, 2016 | DOI 10.1163/9789004304758_006 This is an open access chapter distributed under the terms of the Creative Commons Attribution- 
... land grabbing may be as much the result of host state action and domestic power dynamics as of foreign pressure (Fairbairn, 2013, 352)

An integral part of the current boom in agricultural commodity production is investments in sugar cane and bioethanol-investments that often involve large land deals. So far, much attention has been paid to foreign investments and transnational actors who acquire or lease land and invest in commodity production as a response to the increase of prices at the world market. Evidence suggests that in many areas of Asia, the squeeze on natural resources and farmers' landholdings is caused by a less visible, longer-term process of land acquisition by local and national elites, often — but not necessarily-in conjunction with foreign investors (McCarthy et al., 2012). Relatively little consideration is given to the complexities and trajectories of deal making and implementation processes (Borras Jr. and Franco, 2010). Many deals turn out differently than originally envisaged by the investors, state agencies, stakeholders and NGOS. Once an investment scheme has been announced or a contract has been signed, implementation problems arise due to the competing strategies and interests of investors, government departments, workers, landowners, and brokers, and due to specific historical and institutional settings (Bakker et al., 2010, 168; Fairbairn, 2013, 137; Hall et al., 2011, 4).

In this chapter we argue that land deals are to be understood as processes of constant negotiation and adaptation. McCarthy et al. (2012, 556) emphasise the need to move beyond 'more structural accounts that privilege transnational forces that have a tendency to overlook local agency and difference'. In understanding these processes, we therefore build upon approaches that see the dynamics of changing regime interests, state policies, agribusiness agendas, traders, and farmers as being mutually constitutive, 'cumulatively shaping local production networks' (McCarthy et al., 2012, 556). The way these elements work together in a particular location affects the pathway of investments (McCarthy et al., 2012, 556). We are further inspired by writers such as Tsing (2005) who wrote that 'global forces are themselves congeries of local/ global interaction' producing friction but also new coalitions and alternative forms of interaction.

This chapter aims to understand the complex processes of investment and land deal making through the in-depth study of three different implementation trajectories of sugar cane investment schemes-one in northern Luzon, the Philippines, and two in Aceh, Indonesia. Although investment and devel- 
opment policy play a central role in promoting and shaping large land deals in their initial stages, the relevance of policymaking and adaptation during the dealmaking process is often neglected. We argue that a processual approach to the analysis of land deals is needed to produce insights and tools that make monitoring and policy adaptation possible. Key questions concern which trajectories are unfolding, which actors are important, and how local conditions play a role. What can we learn from the different outcomes of these sugar cane investment schemes and how significant are the different investment trajectories for policy? To examine these questions, we reconstruct the social history of dealmaking in three schemes of government-supported sugar cane investment and the implementation processes relating to such deals. We begin this article with the current outcomes of the three investment schemes, after which their investment trajectories will be analysed and described in detail. We identify the collaboration of investors and bureaucrats; control of the development agenda; land deal making and control over land; control of labour; and curbing resistance as key junctures at which the land deal process took a decisive direction which affected or influenced the specific land deals presented in the paper.

\section{Research Locations and Investment Trajectories}

The research locations are Isabela in northern Luzon, the Philippines, and Aceh in Indonesia. In the former, one area was studied (Isabela); in the latter, two (Central Aceh and Bener Meriah). In all three locations the respective national governments tried to attract foreign companies to invest in sugar and biofuel production. The interest in sugar cane emerged as a result of the global boom in agricultural commodity production, the rising prices of sugar and biofuels, and the gradual abolishment of domestic subsidies due to global and regional free trade agreements. In 2006, ${ }^{1}$ in Isabela, a biofuel production unit was established as a joint venture of foreign and domestic investors. In Aceh, sugar cane was a well-established crop in Central Aceh and was newly introduced to Bener Meriah in 2009.

The original plan of the Taiwanese, Japanese, and Philippine investors was to establish a biofuel company, Green Future Innovations Inc. A domestic company_Ecofuel Land Development Inc.-would supply the feedstock by developing 11,000 hectares of sugar cane plantation in the municipality of San Mariano using contract farming. However, the investment scheme was not executed as intended due to resistance from NGOs, the disinterest of farmers,

1 The activities began in 2006 although the companies were registered in 2009. 
and complex property rights. In order for the plantation company to concretise its plans, it shifted to short-term lease contracts and brought in cheap and experienced sugar cane workers from elsewhere. The bioethanol plant to which Ecofuel supplies feedstock began operating in 2012, albeit with lower production levels than originally envisaged because Ecofuel could not yet comply with the required volume of delivery.

The two cases in the Gayo highlands of Aceh show very different investment processes, which result in opposite outcomes. Various local varieties of sugar cane have been grown by local smallholders in Central Aceh since the mid-196os. Since then, sugar cane has been processed into red sugar for the local and regional market in simple, locally built and owned processing units. As part of a governmental programme to boost biofuel production, in 2009 the Indonesian government financed the establishment of a biofuel plant in Central Aceh. But this bioethanol plant could not compete with the local sugar factories, due to weak management, bureaucratic inefficiency, price distortions of the domestic biofuel market, and a lack of feedstock supply. As a result, the biofuel plant never became operational. Two years later, another attempt to establish an industrial processing plant took place when the Singapore-based company Indo-China Food Industries PTE Ltd began planning to develop a sugar factory. In 2011, Singaporean investors signed a contract with the Central Aceh district government to invest in a sugar processing plant. In 2012, a joint venture, Pт Kamadhenu Ventures Indonesia, was established and by mid-2013, the construction of a sugar factory had begun and land was made available by the local government. The new investors managed to flexibly adapt to the local situation by starting with processing locally produced sugar cane so as not to compete with local production units.

The case of Bener Meriah provides a different story. The sugar investment area in Bener Meriah is situated on the old front line that separated the Free Aceh Movement (Gerakan Aceh Merdeka, GAM) and the Indonesian Army. The area was depopulated as a result of strategic evictions and war atrocities during the peak of the civil war from 2000 to 2003. The old front line separated ethnic Acehnese in the eastern coastal districts, who mainly supported GAM ideology, from native ethnic Gayonese and Javanese migrants in the highlands, who were neutral or in favour of the Indonesian government. Following the war, this depopulated area became a target of post-conflict development schemes aimed at reintegration and rehabilitation. The central Indonesian government, while trying to attract investors, spent a significant amount of money to introduce high-yield sugar cane varieties and boost smallholder sugar cane expansion. The district and central governments attempted to provide a labour force for the expected investors through resettlement and transmigration programmes oriented towards Gayo and Javanese migrants who had 
been evicted and lost land during the war. The district government also tried to provide large tracts of land for the investors by proposing a reduction in state production forest. However, despite policies and programmes from the national and provincial governments to attract foreign and domestic investors, overseas investors pulled out due to the many difficulties they experienced acquiring land in the post-war landscape, and therefore no processing plant was ever constructed.

The programmes to introduce sugar cane, implemented by the district government of Bener Meriah and financed from national and district budgets, were successful in the sense that settlers-some returnees and some newly resettled inhabitants-started to grow sugar cane. The programmes enabled local investors to invest in land and simple processing units of the same type as in Central Aceh. Ethnic Gayo elites and bureaucrats profited significantly from these programmes, while former landowners and Acehnese war victims were excluded. Large difficulties were encountered in the introduction of the crops and with regard to access to land and the distribution of benefits. Meanwhile, traders and small and medium-sized entrepreneurs, army personnel, and government officials from nearby towns and even from North Sumatra and Java did acquire land and started to grow and produce sugar cane for the local and regional market. Unrefined, red sugar is now produced, by smallholders, for the local and regional market in nearby district capitals (Takengon, Simpang Tiga Redelong, and Bireuen) and for soy sauce factories in Medan, in North Sumatra province.

In all three cases, interventions clearly had different results than expected and governance of the investments was a rather complex and ineffective process. The impact for local people was mixed. In the Philippines, the interventions resulted in land leases from smallholders and contract farming arrangements that benefitted mid- and large-scale farmers. The establishment of a partly foreign-owned bioethanol plant was facilitated, but not managed, by the government. In Central Aceh, initial government investments failed, but foreign, private investment materialised and investors manoeuvred through local mechanisms and by making use of an existing sugar cane market-a process which occurred without much government involvement. In Bener Meriah, many rural development schemes and government interventions were implemented and the national and district governments tried to convince companies to invest in the area, but following initial agreements and field surveys, foreign and domestic investments did not-in the end-materialise. The government then turned to rural development programmes aimed at growing sugar cane. These interventions can be understood as attempts to restore state control over the old front line area and to exercise security measures for sake 
of the Indonesian government vis-à-vis the GAM, which has dominated provincial politics since the 2006 elections. As a result, government officials and local and regional pro-Indonesian entrepreneurs did profit, while most of the war victims, especially the Acehnese, were left out.

A more detailed explanation and analysis will be provided in section 6 regarding the interventions and local outcomes.

\section{3} Analytical Framework

In this chapter, we focus on sugar cane, since this agricultural commodity has attracted renewed interest not only from the government and investors but also from scholars researching the global land-grab phenomenon. Rather than focusing on international actors, here we will emphasise shifting power dynamics and competing actors at the sub-national level in the course of land investments. In doing so, we adopt a 'processual' approach to understanding the evolvement of investments in sugar cane crops and land over time in the Philippines and Indonesia. A processual approach involves the study of processes rather than of discrete events and separated actions. In our understanding, investments should be studied as trajectories of dealmaking, and understood as extended processes of negotiation and adaptation stretched over time. In the following, we will outline some basic elements of this processual approach to clarify the social reality of policy and business investments. We will also explain why this processual approach is relevant for policy.

A study of land deals as processes draws upon several bodies of literature. The first concerns an interactional perspective, understanding land deals as arenas of struggle and contestation in which different stakeholders compete over resources and profits (Bakker et al., 2010; Bierschenk, 1988; Long, 2001; Olivier de Sardan, 2005). In this competition, the issue of access to resources and the benefits of the intervention is pivotal. 'Access always involves insecurities due to contested forms of legitimisation, the opportunity of employing multiple sources of legitimisation (including state law, international human rights and claims of ancestry), the absence of a single regulating authority (such as the state) and the relative nature of access (relative to other contenders). Intervention is, therefore, subject to continuous contestation, renegotiation, bargaining and accommodation through which all the parties involved may land up with some access and control' (Bakker et al., 2010, 168). Local actors cannot predict the outcome of such interactive processes; neither can academics, who are also constrained when endeavouring to make absolute statements on rights of access. 
We can also learn from the francophone research on development interventions, of which Bierschenk $(1988 ; 2008)$ and Olivier de Sardan (2005) are major proponents. It is revealing to apply their earlier research-into the implementation of development projects-to investment schemes in agriculture, in order to understand the transformation of original goals into new outcomes and social realities. 'Project implementation does not mean carrying out an already-planned programme but is a constant process of negotiation. One must begin with an analysis of the project's participants and other interest groups, the goals and reasons for their negotiations, resources they have at hand -in short, of their own respective projects' (Bierschenk, 1988, 146).

In post-conflict areas, securitisation is the key force in this process, as competing parties articulate concerns on 'security matters' to legitimise their different political and economic stakes during the critical period of transition to peace. However, rather than reflecting on an objective threat, this kind of politicisation constitutes a 'securitising move' by powerful actors (especially, in this case, by former rebel and pro-Indonesia leaders), through which certain issues are elevated to the status of 'security matters' in order to be handled with the politics of emergency, thereby bypassing normal democratic procedures and necessary technical requirements (Buzan et al., 1998). In the context of post-war Aceh, such securitisation is not merely an appropriation of the language of peace building to justify [...] various predatory economic behaviours' (Aspinall, 2009, 17); rather, it is also a means for the national government to control certain areas and target loyal subjects through agribusiness and development schemes.

If we want to understand these processes in more detail and bring lowlevel actors and groups into focus with global developments, the market, and local and national structures of unequal power relations and state dominance, we need an understanding of 'the service of go-betweens or mediators who occupy a clearly strategic position' in this process (Olivier de Sardan, 2005, 173). Again, here we draw on the rich literature on development interventions and improvement schemes, particularly that of researchers who carried out pioneering work on understanding brokers and brokerage (Bierschenk et al., 2002; Lewis and Mosse, 2006; Olivier de Sardan, 2005). It is revealing to apply this literature on development interventions and improvement schemes to understanding investments and development schemes as interventions. '[Central] is the premise that [such an approach] can provide policymakers and aid managers with valuable reflective insights into the operations and effectiveness of international development as a complex set of local, national, and crosscultural social interactions; and it is no longer possible to isolate interactions 
in the realm of development from those related to state apparatus, civil society, or wider national or international political, economic, and administrative practices' (Lewis and Mosse, 2006, 1).

The actions of investors, entrepreneurs, government officials, NGOs, gobetweens and middlemen are entangled in wider structures of power, dependency, inequality, culture and agro-ecological conditions. They are shaped by institutional legacies and historical repertoires that differ at different times and in different places. We thus cannot overlook the mediating role played by national-level institutions and domestic class inequality in determining the actually existing outcomes of agricultural commodity investment. We focus on the processes of brokerage between state development schemes, market opportunities, investor interests and local smallholders and labourers.

Such a focus on the role of domestic elite mediation is important, in part, because it belies the 'win-win' narratives on large deals currently being promoted by the World Bank and the FAO, among others. Fairbairn's (2013) study on foreign land investments in Mozambique finds that indirect land dispossession is the result of the mediating role played by domestic elites. She identified five sources of power that privileged domestic actors in their relation to foreign investors: traditional authority, bureaucratic influence, historical accumulation, locally based business knowledge and networks, and control over the development agenda. These largely correspond with the critical junctures we identified in Isabela and Aceh, as we shall see in the following sections.

\section{$4 \quad$ Approach and Methodology}

Investments are shaped and mediated by the institutional, political, and economic context in which they are made. A historical 'institutionalist' approach adds to the understanding of why certain investments materialise and others do not and what particular shapes investments take. 'When political institutions are weakened during transition periods, allocations of power and resources become open for competition' (Bertrand, 2004, 10). These periods of institutional change constitute 'critical junctures', during which the institutionalisation of social and economic relations is modified along with a reaffirmation, contestation, or renegotiation of the principles upon which these relations are based (Bertrand, 2004, 10). For this chapter, we identified the 'critical junctures' in the investment process - the crucial moments of dealmaking and interactions in which the relations between investors, the state, institutions, and local actors changed or were renegotiated, reconfirmed, and reconfigured. 
During data collection, the extended case method (Lund, 2014; Van Velsen, 1967) was used to follow the dynamic interaction and the different processes in land deal making and investment concretisation. Fieldwork was spread over a 10-month period in Isabela and the Gayo highlands, and consisted of interviews, participant observation, and data gathering at the village, municipal, and provincial levels. A survey was also carried out at the village level where the biggest concentration of sugar cane interventions took place. In the research, respondents included women and men, farmers and farm workers, labour contractors, company field staff and officials, traders, local government officials, and representatives of government agencies. In Aceh, former GAM combatants and anti-GAM militia members were also interviewed.

\section{National Policies around Sugar Cane Expansion}

Agricultural commodities such as sugar cane have attracted renewed attention during the current agricultural boom following the convergence of multiple global crises involving finance, food, energy, and climate. The Philippine and Indonesian governments' decisions to exercise new policies for the expansion of sugar cane production can be understood as attempts to create economic opportunities from these crises through commodities characterised as 'flex crops $^{2}$ (Borras Jr. et al., 2014). At the same time, the special treatment that sugar as a commodity demands, as a 'special/sensitive product' within free trade regime, provides some flexibility for both governments to establish a set of policies for allocating land, attracting private investments, and enhancing control over sugar cane downstream products (either biofuel or sugar).

\subsection{Policies on Biofuels in the Philippines}

Historically, the sugar cane sector had a special position in the Philippines, cane being its most important export commodity between the late eighteenth century and the mid-1970s. Large sugar estates, haciendas, were the basis of wealth for an important part of the Filipino elite-a landed elite that still has strong political influence as well as stakes in many agro-commodity firms. In 2007, the Philippines was the 1oth largest sugar cane producer in the world and second to Thailand among South-East Asian countries (Fischer, et al., 2008, 31). The island of Negros can be considered as the sugar base of the country, with almost half of the country's total sugar cane being produced by its thirteen sugar mills. While a small proportion is still exported, production is now

2 Borras Jr. et al. $(2014,2)$ define flex crops as crops and commodities that have multiple uses (food, feed, fuel, industrial material) that can be, or are thought to be, flexibly interchangeable. 
primarily for the domestic market, given the fast-growing population and rising domestic demand.

Investors are seeing sugar cane cultivation in a new light with respect to the growing popularity of green energy. The Philippines has joined the biofuel production hype with the aim of generating revenue while embarking on clean energy promotion, having become a signatory to the Kyoto Protocol. The country thus sees a future for biofuel use in the country and is now a marginal biofuel producer. Policies have been put in place to further this objective, most importantly the Republic Act 9367 — better known as the Biofuel Act—of 2006. It requires the phasing out of harmful gasoline additives and the use of a minimum of 10 per cent bioethanol blend in all gasoline fuel sold and distributed in the country. Joint Administrative Order No. 1, Series of 2008 identifies proposed biofuel production sites as priority development areas for land conversion. Such areas are 'underutilized and marginal'; 'irrigated and irrigable lands, especially those used for rice production' cannot be used for biofuel crop production. At least two million hectares of the country's lands are targeted for agribusiness production, including crops for biofuel and agroforestry (NEDA, 2010). Sugar cane is expected to play an important role in this. In addition, sugar cane planters supported the Biofuel Act in view of the possible reduction of import tariffs on sugar because of the Association of Southeast Asian Nations (ASEAN) economic integration scheduled for 2015.

\subsection{Overlapping Policies on Sugar Cane in Indonesia}

In Indonesia, many paradoxes can be found in national sugar cane policies. One set of policies aims to increase national sugar production as part of national food security policies. Being heavily dependent on imported sugar, the government issued an ambitious policy in 2009 to achieve sugar self-sufficiency by 2014. To meet this target, as much as 350,000 hectares of new sugar cane area were to be developed, including Bener Meriah in Aceh (El Hida, 2011). Another set of policies targets sugar cane as a priority crop in an attempt to boost biofuel production by complementing the existing production of palm oil as biofuel. These policies are framed as a key part of the 'national energy mix' policy ${ }^{3}$ stipulated by Presidential Regulation No. 5/2006, which envisions biofuel consumption constituting 5 per cent of total energy consumption in Indonesia by 2025 .

3 The Indonesian 'national energy mix' policy envisages that fossil oil consumption would constitute less than 20 per cent of total energy consumption by 2025 as total energy demands would be met from various energy sources including fossil oil, biofuel, natural gas, liquefied coal, and other renewal energies. 
With this kind of overlap in policies and agenda setting, the Indonesian case provides a sharp contrast to the Philippine case, where strong, clear-cut policies on biofuel production were put in place. In the Philippine policy context, downstream oil industry deregulation allows private companies to invest in the biofuel industry. Its clean air policy demands emission reduction and the promotion of biofuels as a cleaner fuel alternative. The government of the Philippines has clearly made an effort to promote biofuel production-also because the country has no oil itself. The Indonesian policies, on the other hand, got caught in contradictions and never manifested as intended. Reasons for this include conflicting policies for sugar self-sufficiency, a national energy mix, and post-conflict development assistance to facilitate the return of refugees and to involve them in sugar cane production.

As we indicated in the previous section, the differences between investments in biofuel and the need to enhance food production both in the Philippines and Indonesia have created conditions with regard to policy and institutional frameworks under which investments in sugar cane could thrive. However, as we will argue in this section, the specific outcomes of sugar cane interventions have a lot to do with sub-national power dynamics mediated by local elites with strong political and economic interests. The contrasting interests of local actors make straightforward implementation of national policies impossible.

\subsection{Sugar Cane Investments in Isabela, the Philippines}

In retrospect, the specific trajectory of sugar cane expansion and change in land and labour contracts in Isabela can be understood by taking a closer look at several critical junctures where a decisive direction was taken. In the following section, we follow the processual approach and identify the following junctures: protest and adaptations; bureaucratic support; the change from (intended) land acquisitions to land leases and contract farming; the establishment of beneficial labour contracts for local residents and the introduction of cheap and efficient labour from elsewhere; control of the development agenda; and the close cooperation between investors and local elites.

The investment plans evolved successfully due to a number of factors. In the beginning, the investment received a lukewarm reception in the villages because sugar cane cultivation was new to the locality. Some local farmers' groups associated with bigger groups campaigning against large-scale land investments in the Philippines also vigorously campaigned against it. To these 
groups, the establishment of the sugar cane investment violates the land and labour rights of local farmers, not to mention the threats to the environment and local food security (Aonishi et al., 2011) that such investment entails. Nevertheless, the investment scheme was established and has been operating now for eight years - albeit with deviations along the way. Local government played a crucial role in facilitating the entry of investors and the selection of the municipality of San Mariano as the main location of the investment. Once the area was identified by the central government, the investors had to deal with local government units. Ecofuel negotiated with provincial- and municipal-level officials in order to gain entry to the villages and identify plantation sites. The investment scheme received the endorsement of local government units and was hailed as one of the top investments in the province and the biggest active bioethanol project in the country. Provincial promotion brochures prominently feature Ecofuel's production areas and Green Future Innovation Inc.'s (GFII) bioethanol plant.

The decision-making process lacked transparency and it excluded smallholders. Village officials agreed to organise assemblies to promote the investment scheme at the village level, but the nature of the project and its possible implications for the community were not explained to the villagers, and nor was their input requested with regards to the introduction of sugar cane into their areas. The village officials could have played an active role in this. The village assemblies could have been utilised as platforms for dialogue on the acceptability of the investment scheme.

Ecofuel Land Development Corporation was registered as a corporation in 2009 , but as early as 2006 had signed contracts with farmers and begun developing the sugar cane nurseries. Currently, two main types of arrangement are enforced by Ecofuel: lease and contract farming. Lease contract is the dominant scheme implemented by the company. The lease agreement usually covers three years and is renewable for another three years. The rent ranges from PHP 5,000-10,000 (roughly EUR 88-176 in 2014) per hectare per year depending on the distance of the farm from the processing plant. The company takes over the land for the duration of the contract, organising production and recruiting labourers.

The contract farming scheme requires that the landowners work or at least supervise the farm work themselves. The company advances the production costs, optionally including labour costs, then deducts these from the grower's earnings in the harvest period, computed at PHP 1,200 (approximately EUR 21 in 2014) per ton of sugar cane. Contract farming is the company's preferred option, as it makes controlling the quality and productivity of the land possible and saves on the cost of organising labour. Moreover, all production risks are born by the farmer, not by the company. 


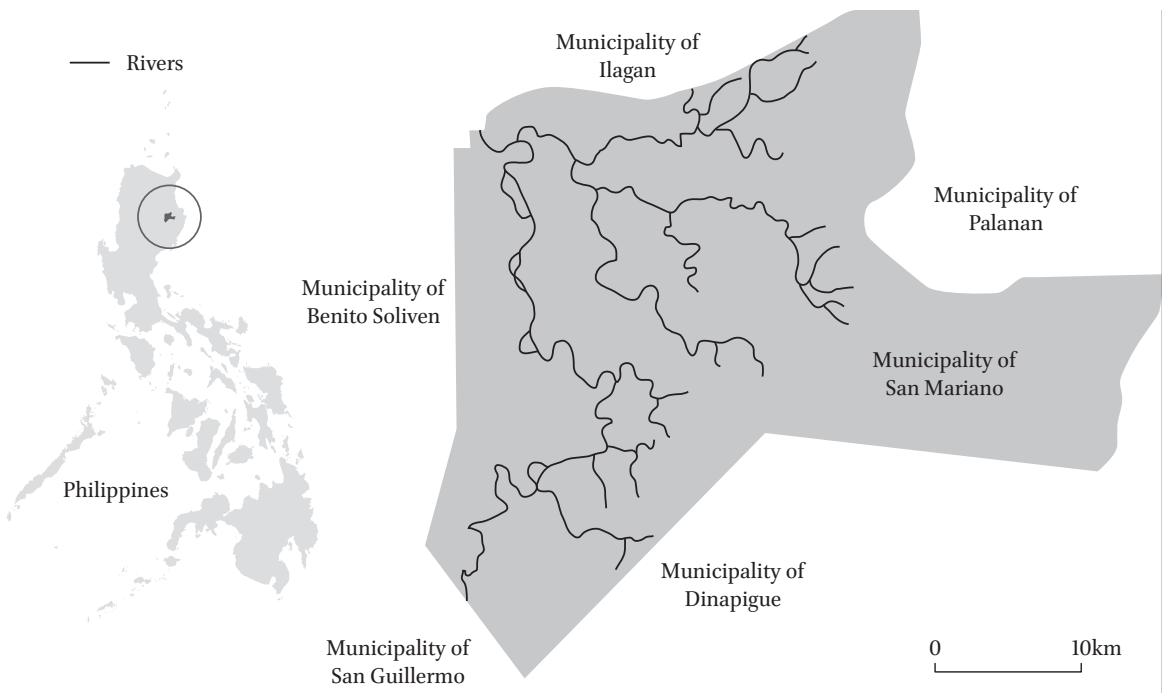

FIGURE 5.1 Map of San Mariano, Isabela (the Philippines).

SOURCE: MUNICIPAL PLANNING AND DEVELOPMENT OFFICE, SAN MARIANO, ISABELA, 2012.

Another intervention, this time by the investor, was to capitalise on existing social relations in the villages in order to acquire land and labour. The company hired locals as technicians and labour contractors. Company technicians conducted house-to-house visits but only to convince farmers to lease their lands and with very little explanation regarding the terms of the contract. The farmers needed convincing, so technicians emphasised the possible earnings, the advance rental payment, and advances for production costs to be provided by the company. Using its local personnel to promise incentives to farmers already facing economic constraints was an effective approach for the company.

Traditional big landowners turned out to be useful entry points for the company to gain access to land through lease or contract farming. They were the first to be contacted during plantation development and their lands were used for establishing nurseries. Despite the five-hectare ceiling on land ownership imposed under the agrarian reform programme, there are still landowners who possess at least 20 hectares, with one prominent landowner reportedly owning about a hundred hectares in one village. During village assemblies, the company officials used the experience of the big landowners in their dealings with Ecofuel to entice small farmers to lease out their lands to the company as well. The contract farming and lease arrangements with big landowners served 
as a guarantee that the investor could be trusted. At present, the majority of the lessors and contract growers are small-scale farmers owning less than five hectares. Their areas converted to sugar cane were previously either not utilised, or used as pasture or cultivated for rice, corn, or vegetables.

The outcome of all these negotiations was that the planned contract farming arrangement preferred by Ecofuel did not materialise for the majority of its production areas. In the first years following the establishment of the scheme, almost all lands were leased for three years and workers were recruited to work on the leased lands. Labour contractors, on the other hand, were already experienced in pooling farmworkers to work in small groups on rice and corn farms. They could also easily mobilise labourers to work for Ecofuel. Nevertheless, a number of labour contractors recruited labour from traditional sugarproducing provinces in the Philippines beginning in 2006. Working for nine months in a year, the farmworkers are hired as migrant labour to perform the harder tasks avoided by the local farmworkers - for example the harvesting of canes and their transport to the processing plant.

Another setback for Ecofuel was that it could not develop its targeted 11,00o-hectare plantation site in San Mariano because not all farmers wanted to give up farming. It changed its strategy and looked into adjacent municipalities and provinces for possible production areas. Lease and contract farming remained the two schemes offered by the company. In addition, Ecofuel encroached upon existing sugar cane-producing municipalities in neighbouring provinces and started buying sugar cane that was destined for the existing sugar mill in the region. The competition resulting from the entry of Ecofuel into these markets has been an unpleasant surprise for the existing sugar mill, but the resulting better prices for harvested cane have been welcomed by sugar cane farmers.

Existing socio-economic inequalities and political power differences provided leverage to the elite in dealing with Ecofuel. Members of the elite are able to bend company rules - such as not signing formal contracts or changing the nature of agreements, for instance from contract farming to self-financing. By comparison, smallholders were not given a choice as to which production arrangements were available to them, nor did they receive advice from local officials about the possible problems they could encounter if they contracted out their lands.

Smallholders also complain about the lack of government assistance with regard to the establishment of the sugar cane investment schemes. For them, the investments did not bring much benefit. But, true to its market-orientation, the Philippine government limited its role to identifying potential areas of production for large-scale land investments, leaving it up to companies and 
landowners to negotiate the terms of their engagement, as is the case with Ecofuel.

Due to all these difficulties, adaptations, and time-consuming negotiations, investing in Isabela was quite complex for Ecofuel. Moreover, they faced opposition from organised farmers' groups from early on. These groups had their own intervention strategies with which to resist the investment. The company suffered losses due to its equipment being burned by militant groups. Some mobilisations in 2011 and 2012 involved the uprooting of newly planted canes and the setting up of blockades to stop operations in areas where land ownership was contested. The workers also organised strikes in one of Ecofuel's farming areas and in the processing plant of GFII in 2012, which also paralysed operations at one point. Complaints of violation of environmental regulations were lodged against GFII but the company was only issued with a warning by the environmental management agency.

The company had its own strategies with which to respond to actions protesting against the investment scheme. Ecofuel pulled out from some of its production areas to counter such opposition. Halting operations affected the employment conditions of the local farmworkers. The lands of contract farmers were, in some areas, not maintained, which meant lower cane quality and thus a lower market price. Ecofuel alleged that local officials had not protected them from the militants' actions. Meanwhile, those campaigning against the investment criticised the inaction of local and national government agencies regarding environmental, labour, and land grabbing complaints lodged against Ecofuel.

We can observe a number of critical junctures in the investment and implementation processes. At these junctures, the interests and agendas of community elites, state actors, and investors came together. This collaboration (Tsing 2005) allowed the company to jump-start its operation in the municipality. Resistance to the investment was effective in the short term, but the investor was able to adapt and change its strategies, which restrained the opposition's initial gains. The investor also managed to control land and labour through its flexible adaptation of production schemes and the labour regime. The investment offered income and employment opportunities to small farming households, but the landed elite profited more through the better deals that they negotiated with the investor.

\subsection{Sugar Cane Interventions and Investments in Aceh, Indonesia}

In comparison with Isabela, the specific trajectory of sugar cane expansion and the establishment of a bioethanol plant in Central Aceh, and the failure of foreign investments in Bener Mariah, should be understood in the historical 
context of post-conflict interventions and peace agreements. These sugar cane investments took place in a post-war environment. In this context, complicated land tenure as an outcome of war atrocities, and new provincial and district power reconfigurations following the peace agreement and the 2006 local elections, became the two main factors influencing the process of investment in sugar cane and land over time.

After the conflict, local elections were held throughout Aceh province in December 2006. In these elections, former GAM strategist Irwandi Yusuf was elected as Aceh's governor, (henceforth referred to as 'Governor Irwandi'), while in the Gayo highlands former anti-GAM leader Tagore Abubakar was elected as district head (Bupati) of Bener Meriah district (henceforth referred to as Bupati Tagore). Both these leaders, and other key players in the intervention, had access to development funds provided as a 'peace dividend' and soon engaged in intense contestations regarding post-conflict development agendas-including the agribusiness sector-contestations that replicated and even sustained conflict-era antagonism.

The specific trajectory of this intervention can again be understood by taking a closer look at the junctures at which critical decisions were made. In the following section, we look at critical junctures such as governmental and bureaucratic cooperation; control over and contestation regarding the development agenda; available production repertoires and agricultural histories; the control of land and labour; and the role of labourers, migrants, and local business elites.

Three mid-slope areas in the Gayo highlands were targeted by the national government for various sugar cane schemes following the conflict (see Figure 5.2). The first location, the Pantan Tau plateau in Central Aceh, ${ }^{4}$ has been a sugar cane producing area since the mid-196os. Pantan Perempusen (location 2) and Rime Mulie (location 3), both in Bener Meriah, are situated in the former frontier areas. Tens of hectares of sugar cane existed there just before the war, but all disappeared due to the conflict: war atrocities were rampant in the area. While only a few people were displaced in Pantan Tau and sugar cane production continued without major interruptions during the war, many villages in Pantan Perempusen and Rime Mulie sub-districts were depopulated, while most of the sub-districts' agricultural areas became grassland or shrub land. This not only created a drastic change in the rural landscape but also led to land tenure insecurity after the war.

4 Pantan Tau and other names used for sub-districts and villages in this paper are all pseudonyms. 


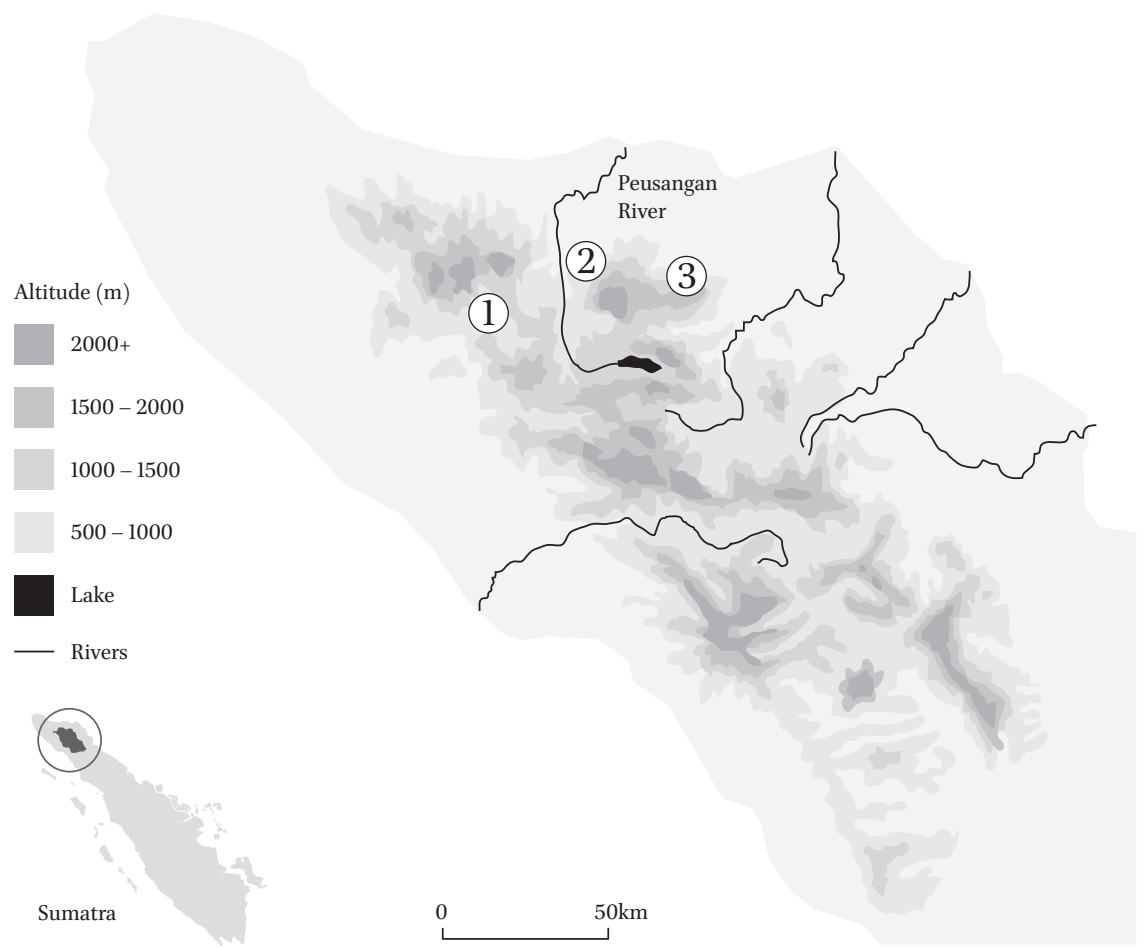

FIGURE 5.2 Map of the Gayo highlands and areas targeted by sugar cane interventions (Indonesia).

Note: Location 1 is Pantan Tau plateau; location 2 is Pantan Perempusen sub-district, and location 3 is Rime Mulie sub-district. SOURCE: BOWEN (1991).

\subsubsection{Sugar Cane Investments in Central Aceh}

In contrast to the two areas in Bener Meriah, foreign investors found more land in Pantan Tau, Central Aceh with which to pursue their investment plan. Firstly, no 'post-war land' existed there since the area had been classified as a 'white zone. ${ }^{5}$ Secondly, in the aftermath of the conflict, territorial and population control measures in this region had never become a matter of contestation or the subject of securitisation, such as they had in Bener Meriah. Last

5 During the war, the Indonesian military classified Aceh territory as 'black', 'gray', or 'white' zones according to the degree of their control over that territory and to the GAM's presence there (see Aspinall, 2008). 
but not least, Pantan Tau is a well-established sugar cane area covering around 8, ooo hectares of low productive sugar cane, which could provide the initial supply to feed the sugar cane processing plant.

The first attempt to invest there was made by the central government. In 2009, the Ministry of Industry built a plant to produce bioethanol—from sugar cane molasses - with a production capacity of around 3,00o litres per day. The plant cost IDR 16.172 billion (approximately EUR 1 million), and its construction was financed by the central government national biofuel programme. Its operation would depend on the supply of local sugar cane through free market mechanisms. The plant, however, never became operational since the plan did not work. Without adequate initial capital and due to the distortion of a highly subsidised fossil oil price, the plant's competition for feedstock with the local red sugar processing units made biofuel production uncompetitive. Thus, farmers continued to process their sugar cane for red sugar rather than selling it to the bioethanol plant, which offers much lower prices.

Soon afterwards, Pantan Tau was targeted for foreign investment by Singapore's Indo China Food Industries PTE Ltd. The investors were interested in investing in a sugar cane processing plant and in sugar cane estates. On 24 October 2011, a Memorandum of Understanding (MoU) was signed in Takengon, the capital of Central Aceh, by the managing director of the company and the Bupati of Central Aceh district. The MoU stated that the company would invest in the sugar cane processing complex, which would produce sugar, electricity, and ethanol.

For the first stage, a total of USD 7.5 million was to be invested in a processing plant capable of managing 3,500 tonnes of cane per day (TCD). This could be expanded to about 10,000 TCD depending upon the economic viability of such an expansion and the development of sugar cane estates around the factory. While the plant in its initial phase would depend on supplies from local farmers, in order to be able to increase its production capacity in the next operational step the company demanded that the Central Aceh district government allocate at least 10,000 hectares for a sugar cane plantation. If the plant's production capacity did expand to 10,000 TCD, a further 30,000 hectares was to be provided by the district government.

In response to this demand, the Central Aceh district government allocated 10,00o hectares of state land and of ex-plantation concession (Hak Guna Usaha, HGU) in Uning Gading, around $35 \mathrm{~km}$ from the north western side of Pantan Tau. An additional location was still to be found, which would most likely imply the reduction of production forest areas. Although the company had not yet started the land acquisition process in Uning Gading, rumours regarding the 
search for land for plasma estate ${ }^{6}$ development had spread widely throughout the highlands since late 2011, triggering land speculation and a rush on land.

By mid-2012 the company had established a joint venture company, PT Kamadhenu Ventures Indonesia, and by early 2013 this joint venture had started to purchase 75 hectares of land in the centre of Pantan Tau to establish a factory complex. This process was accomplished in June 2013, and the following month the first stage of construction officially began. Although the construction process was interrupted by a big earthquake, which hit the area in July 2013, it resumed some months later. Factory construction was still in progress at the end of our fieldwork period.

Critical junctures in the investment process were: the co-optation of national and local units of government; converging development agendas; the ability of the foreign company to adopt a flexible and phased business plan; the shift to market based approaches, which curbed the opposition of farmers already producing sugar cane; the provision of land by the district government; and the availability of cheap labour and an experienced work force.

\subsubsection{Sugar Cane Intervention in Bener Meriah}

In the third case study area, Pantan Perempusen and Rime Mulie, in Bener Meriah-largely depopulated due to the massive outflow of refugees-any attempt to bring in agribusiness investments had to address the problem of a labour shortage and a general lack of agricultural inputs. The central and district governments, in their attempts to attract investors, therefore made great efforts and spent a significant amount of money to mobilise labourers and investments in crops and to allocate large tracts of land. In this regard, three interventions have been carried out by the government since 2007: the first was labour mobilisation, the second was the introduction of sugar cane, and the third relates to land allocation for sugar cane investments. These interventions were extremely complicated due to the problematic nature of securing the cooperation of local elites; conflicts over development agendas; GAM protests; and securitisation struggles, all of which constitute the key critical junctures in this case.

In relation to labour, in mid-2007 Bupati Tagore facilitated the arrival of 136 families of conflict refugees and resettled them in Blang Bintang village, Pantan Perempusen. Interestingly, these families were mostly former Javanese

6 The term plasma estate refers to a specific arrangement of contract farming between a company and smallholders in Indonesia in which smallholders are provided with agricultural supports (and sometimes with access to land) to produce a specific commodity as required by the company. 
(trans)migrants who had fled from various parts of Aceh during the war, but none originated from Pantan Perempusen. Thus, rather than prioritising former inhabitants, this programme targeted a group of refugees completely foreign to the area, but loyal to the Indonesian state. In early 2009, after living in tents for more than a year, the families were provided with modest housing built by the Ministry of Social Affairs. The housing complex was located entirely on Bupati Tagore's own land.

Further, Bupati Tagore proposed a transmigration programme through which he expected not only to provide the 136 families in Blang Bintang with houses and pieces of land as promised, but also to mobilise more labours from other provinces in anticipation of the expected rise in labour demand due to the presence of the agro-industry investments. For this purpose, he allocated 9,320 hectares in Pantan Perempusen and 4,200 hectares in Rime Mulie. In addition, a plan to develop an integrated agro-industry in the transmigration area was prepared by the Bupati, all with significant support from the central government (notably from the Ministry of Manpower and Transmigration).

Strong criticism of these agribusiness and transmigration plans was, however, voiced by the GAM. Since mid-2006, GAM spokesperson Bakhtiar Abdullah had reportedly denounced the Indonesian government for discriminating against conflict refugees: 'Many (ethnic Acehnese) migrants who fled from Bener Meriah and Central Aceh are ignored, while transmigrant refugees previously [originating] from Java [have had their moves] fully facilitated and [are] taken care [of]' (Warsidi, 2006). Such criticism - typical of the GAMwas also echoed by Central Aceh's Governor Irwandi, and when a letter of recommendation from the governor was requested as part of the administrative requirements for proposing a transmigration programme, Irwandi refused to sign. A compromise was pursued, and the governor finally agreed to recommend the proposal on the condition that it should be a local rather than a national transmigration programme; that is, the participants could only be Aceh residents - not newcomers from other provinces.

Concerning the second category of interventions (i.e. those related to the introduction of sugar cane), a lot of investment was needed to re-establish the fertility of long-abandoned land in Blang Bintang. Most of the area had been covered by weeds (imperata cylindrica) and frequent grass fires had increased the acidity of the land. The newcomers were paid to clear the land. Yet it was a chaotic and frustrating period for them since certain people claiming to be the rightful owners of the land came to reclaim their parcels after that these had been cleared. Most such attempts failed, with the exception of a handful of pre-conflict landowners with political and economic power, such as government and police officials and army members living in the city, who 
succeeded to secure their land and even accumulated more of it after the end of the conflict. However, most people failed to get their land back.

The first attempts to introduce sugar cane to Blang Bintang took place in 2009. With his good political networks and links-since the war years-to national elites, Bupati Tagore succeeded in convincing the central government to designate Bener Meriah as an area targeted by the sugar self-sufficiency programme. Thus, during 2009-10 significant funds could be drawn from the national budget in order to provide farmers in Blang Bintang with cash assistance for preparing land, purchasing local varieties of sugar cane seedlings and establishing sugar cane plots. At the same time, to securitise the area and place it under his control, Bupati Tagore deployed military battalion 114/sM, purportedly to combat wild boar, the most damaging pest in Pantan Perempusen.

This introduction of sugar cane was a success. In late 2011 a further IDR 1.9 billion (around EUR 119,00o) were provided by the Ministry of Agriculture to develop 50 hectares of nursery plots in Bener Meriah for the purpose of growing a high-yield variety—PSJT 941—in new sugar cane areas in the highlands. Bupati Tagore personally benefitted from these projects since he controlled the programme and located all nursery plots on his own land.

Since 2012, the third sugar cane intervention, again using the PSJT 941 variety produced by three farmers' groups on Tagore's land, has been pursued by the government in order to further expand smallholding sugar cane areas. This programme, to be implemented in several years, involves 120 new hectares of sugar cane production areas in three adjacent villages. The following year, the programme was executed again by the government targeting more land for sugar cane production. To support this programme, the district government of Bener Meriah allocated additional funds from its own budget. This sugar cane expansion attracted a rush of wealthy investors and entrepreneurs who wanted to acquire land and thus buy in to the sector.

In 2010, with the sugar cane introduction programme ongoing, the government started to offer areas of Bener Meriah to foreign investors. On 11 March 2010, the Director General of the Directorate General of Plantation, within the Ministry of Agriculture, chaired a meeting between Bupati Tagore and South Korean Park Energy PTE Ltd. In this meeting, Bupati Tagore offered the investors as much as 17,000 hectares in Pantan Perempusen and 20,000 hectares in Rime Mulie for sugar industry development. Since large parts of the areas designated for sugar cane were classified as state forest, the Director General promised to bring this issue to the attention of the National Team of Sugar Self-Sufficiency Programme, of which the Minister of Forestry became a member. 
Following this meeting, on 29 March, the chairman of Park Energy PTE Ltd Shung Curk Park visited Bener Meriah to start an initial survey. A feasibility study was conducted some months later and delivered a promising result. The investors then stated their interest in investing around ID R 1.8 trillion in Bener Meriah in a sugar cane processing plant capable of handling 10,000 TCD. To feed this plant, the investors demanded that at least 20,000 hectares of land for sugar cane plantation be provided by the government.

Another attempt to attract investors was made by the Minister of Manpower and Transmigration. During his visit to Guangzhou on 28 May 2011, a publicprivate partnership (PPP) to develop sugar cane agro-industrial complexes in the transmigration area was agreed with Chinese state-owned Guandong Agribusiness Ltd. In this PP P scheme, a MoU was signed between the company and Indonesia's P T Pulau Sumbawa Agro (a subsidiary of Pт Kapal Api Group). In accordance with this MoU, the CEO of PT Kapal Api Group and the Director General of Transmigration Area Preparation visited Bener Meriah from 12 to 15 July 2011 to survey potential areas for investment. During this visit, the allocation of at least 15,000 hectares of arable land was discussed with Bupati Tagore - the amount of land necessary to concretise the company's plan to invest in a sugar plant capable of handling 6,000 TCD.

In response to the demand for large tracts of land, the last type of intervention relates to attempts by the Bener Meriah district government to designate certain areas for agro-industry complexes and to allocate land for corporate sugar cane plantation. On 22 December 2010, Tagore issued a decree on the establishment of an integrated agro-industry development area named Garuda in Pantan Perempusen (the Garuda is the Indonesian national symbol and its use by Bupati Tagore reflects his ideological inclination vis-à-vis the GAM ethnonationalist movement). The area covers around 17,00o hectares of 'private land with and without land titling, all kinds of idle land, and state land'. In addition, on 21 February 2011, Bupati Tagore proposed a reduction of production forest to the Minister of Forestry, involving as much as 3,445.32 hectares in Pantan Perempusen and 12,119.25 in Rime Mulie.

Governor Irwandi, however, strongly opposed Tagore's proposal to reduce forest area in Bener Meriah, as he envisioned another agenda for managing Aceh's natural forest and protected areas— - his 'Green Aceh' development plan. His refusal to issue a letter of recommendation for reducing forest area prevented the allocation of the large tract of land necessary for sugar cane investment, and with the land to be derived from forest areas no longer available, the investors found it impossible to continue their investment plan in Bener Meriah. 
Despite the efforts of various schemes for foreign investment in sugar cane plantation in the Philippines and in Aceh, Indonesia, involving investors and the respective governments, of the three cases discussed, only two foreign investment programmes were realised. This outcome of the intervention process can be understood by looking at the differences in the trajectories of the investments and at the decisions taken, negotiations carried out, and adaptations made during the process of implementation. The key decisive moments - the critical junctures - reveal these differences and help to better analyse and understand them.

If we compare the different trajectories, we can identify five key junctures: the collaboration of investors and bureaucratic cooperation between different levels of government; control of the development agenda; land deal making and control over land; control of labour; and curbing resistance.

In Isabela, investments proceeded thanks to co-optation and agreement at most junctures. However, ambitions and control over land and labour changed during the trajectory partly due to refusal of landowners to engage in contract farming and fierce opposition from civil society groups. Governmental policies are clear and coherent and the government is cooperative on all levels. Local landed elites have room to modify deals according to their interests and large landowners profit more than small landowners. The decision to bring in sugar workers from elsewhere and to pull out from conflict-ridden areas led to a further deterioration in the position of the rural poor. At present, short-term lease agreements dominate the production arrangements of Ecofuel. The company uses labour from both migrant and local farmworkers.

In Central Aceh, eventually, the commercially viable investment made in a Singaporean owned sugar plant thrived under free-market conditions. Critical junctures were again the co-optation of national and local governments and the existence of converging development agendas; a shift to market-based approaches, which curbed the opposition of farmers already producing sugar cane in combination with the ability of the foreign company to adopt a flexible and phased business plan; the provision of land by the district government; and the availability of cheap labour and an experienced workforce. Where government investments failed due to mismanagement and as a result of contradictory food and energy policies in Central Aceh, once again the flexible adaptation of the foreign investors turned out to be crucial for penetrating the sugar area. The company did not intervene in the existing situation of local land control. Instead, it adopted a phased business plan that allowed it to rely on local supply for its initial production and only demanded large tracts of 
land in the next phases of its business expansion plan. In the end, the state was largely absent; its attempt at involvement having failed due to mismanagement, conflicting national policies and poor adherence to market laws.

In Bener Meriah, Aceh, Indonesia, implementation of the investment scheme turned out to be much more of a struggle, filled with unexpected turns and moves in which local and regional governmental figures used agricultural investments to enhance political control and to cater to private gains. At most of the junctures conflicts could not be solved and antagonism prevailed. The power play of local authorities and the political, legal, and ethnic complexities present made foreign investors move out quickly. Government investment served other political goals than inclusive development and reconstruction agendas and the interventions were not market driven. However, when the agricultural investments did unfold, new opportunities were created and other parties came in, eager to profit from cheap available land, the introduction of improved cane varieties, and favourable post-conflict business circumstances. For indigenous Gayonese, small and medium-sized investors, and ethnic Gayo elites and bureaucrats, the outcomes of the agricultural development initiatives were rather sweet, and investments ended up being quite profitable, although these benefits were unevenly distributed among them.

For former landowners and pre-war inhabitants from various ethnic backgrounds, however, sugar cane investments provide a bitter outcome since most of them were excluded from these new opportunities. Meanwhile, for newly resettled Javanese settlers, the outcomes were rather ambiguous since only a few have been able to build up savings - from their participation in sugar cane programmes - with which to purchase land, thus becoming independent farmers. The state is significantly involved throughout the process, but juggles security interests, local power plays, and private interests. As a result, contestation and conflict were paramount at almost all the critical junctures and continued over longer periods of time, frustrating foreign investments but favouring ad hoc coalitions of local elites, small farmers, and local authorities.

Investments are usually understood to involve contracts, and contracts to involve two parties. As the cases described in this chapter show, in agricultural commodity investments in Asia, the reality is much more complex and investments are processes. Many more actors are involved and results locally differ from the original intentions of the government parties and investors who signed the contracts. Investors often operate as joint ventures, conjoined 
with local companies, brokers, and elites. It is typically national or provincial governments that facilitate deals and make land available to investors; but after that, other government bodies are involved, with different roles and interests. In the process of negotiations and adaptations to local agro-ecological circumstances and political realities, an increasing number of actors play a role. As a result, the investment process becomes unclear and outcomes are often unexpected and not always sweet.

Hence, while the investments and agricultural development projects represented a common arena of negotiation for all groups involved in the Isabela and Central Aceh cases, and while respective national biofuel and food security policies provided a common ground for legitimation, the different actors used very different frames of reference to guide their social interaction and the rationalisation of their actions. Where in the Philippines free-market narratives and strong anti-liberalist opposition dominated the debate, in Bener Meriah, Aceh, government investments proved essentially to be a fight over territory and people - a continuation of the war by other means. The specific outcomes of the sugar cane interventions thus have a great deal to do with subnational power dynamics mediated by local elites with strong political and economic interests and, in the case of the Philippines, by farmers' resistance.

The three case studies discussed in this chapter show how local tensions and circumstances, as well as conflicts, enable the specific outcomes of investments. In each case, the outcomes did not evolve exactly as planned. Moreover, local forces and power constellations also significantly influence the outcomes of investment schemes. Key junctures are control of the development agenda; collaboration between investors and the government; land deal making and control over land; control of labour; elite and bureaucratic cooperation; and curbing resistance. Our analysis makes clear that this is not a case of companies versus local people, but is rather a much more complex web of interests and struggles in which government parties can play different roles. Our analysis also shows the differential outcomes of investments in terms of control over land, territory, and labour, and of resources divided and distributed among multiple stakeholders; a series of battles over land, labour, and capital, culminating in a sequence of critical junctures. If agreement is reached at one juncture, interests can still be divided at another, critically determining the direction of the intervention. Further research should therefore examine the identification and comparison of such critical junctures and the possibilities for policies to monitor the process by focusing on these junctures. Our conclusions emphasise the unpredictability of intervention processes, as the outcomes of investment deals are far from clear at the start. We believe that understanding the processual nature of land deals and the identification of 
critical junctures have important implications for investment policies and land deal governance. A clear focus on critical junctures in this process will make adaptive and processual policies possible. Which might, in turn, make possible transforming some of the bitter consequences of interventions into sweeter realities along the way.

\section{References}

Aonishi, Y., F. Cosico, R. Gueta, H. Hatae, S. Lovera, E. Maguigad, J. Richardson and T. Roberts-Davis (2011) Not One Idle Hectare: Agrofuel Development Sparks Intensified Land Grabbing in Isabela, Philippines, Report of the International Fact Finding Mission, May 29th-June 6th 2011 (San Mariano: International Fact Finding Mission), http://www.foejapan.org/aid/land/isabela/pdf/20110822.pdf (accessed on 1 June 2013).

Aspinall, E. (2009) 'Combatants to Contractors: The Political Economy of Peace in Aceh', Indonesia, 87, pp. 1-34, http://www.jstor.org/stable/40376474.

(2008) 'Place and Displacement in the Aceh Conflict', in Hedman E-L. E. (ed.)

Conflict, Violence and Displacement in Indonesia (Ithaca and New York: Cornell University Press).

Bakker, L., G. Nooteboom and R. Rutten (2010) 'Localities of Value: Ambiguous Access to Land and Water in Southeast Asia (Introduction)', Asian Journal of Social Science, 38(2), pp. 161-171, DOI: 10.1163/156853110X490872.

Bertrand, J. (2004) Nationalism and Ethnic Conflict in Indonesia (Cambridge: Cambridge University Press).

Bierschenk, T. (2008) Anthropology and Development: An Historicizing and Localizing Approach, Working Paper No. 87 (Mainz: Institut für Ethnologie und Afrikastudien, Johannes Gutenberg Universität), http://www.ifeas.uni-mainz.de/workingpapers/ AP87.pdf (accessed on 4 May 2015).

(1988) 'Development Projects as Arenas of Negotiation for Strategic Groups: A Case Study from Bénin', Sociologia Ruralis, 28(2-3), pp. 146-16o, DoI: 10.1111/ j.1467-9523.1988.tbo1035.x.

Bierschenk, T., J-P. Chauveau and J-P. Olivier de Sardan (2002) Local Development Brokers in Africa: The Rise of a New Social Category, Working Paper No. 13 (Mainz: Institut für Ethnologie und Afrikastudien, Johannes Guetenberg Universität), http://www.ifeas.uni-mainz.de/Dateien/Local.pdf (accessed on 26 May 2015).

Borras Jr., S.M. and J.C. Franco (2010) 'From Threat to Opportunity? Problems with the Idea of a "Code of Conduct" for Land-Grabbing', Yale Human Rights and Development Law Journal, 13, pp. 507-23. 
Borras Jr., S.M., J.C. Franco, R. Isakson, L. Levidow and P. Vervest (2014) Towards Understanding the Politics of Flex Crops and Commodities: Implications for Research and Policy Advocacy, Think Piece Series on Flex Crops \& Commodities No. 1 (Amsterdam: Transnational Institute), http://www.tni.org/sites/www.tni.org/files/ download/flexcropso1.pdf (accessed on 4 May 2015).

Bowen, J.R. (1991) Indonesia Sumatran Politics and Poetics: Gayo History, 1900-1989 (New Haven and London: Yale University Press).

Buzan, B., O. Wæver and J. de Wilde (1998) Security: A New Framework for Analysis (Boulder: Lynne Rienner Publishers Inc.).

El Hida, R. (2011) ‘Butuh 25 Pabrik Gula Baru untuk Swasembada’, Detik Finance, 18 July, http://finance.detik.com/read/2011/o7/18/132717/1683408/1036/2/butuh-25-pabrikgula-baru-untuk-swasembada (accessed on 23 January 2013).

Fairbairn, M. (2013) 'Indirect Dispossession: Domestic Power Imbalances and Foreign Access to Land in Mozambique', Development and Change, 44(2), pp. 335-356, DoI: 10.1111/dech.12013.

Fischer, G., E. Teixeira, E. Tothne Hizsnyik and H. van Velthuizen (2008) 'Land Use Dynamics and Sugarcane Production', in Zuurbier, P. and J. van de Vooren (eds.) Sugarcane Ethanol: Contributions to Climate Change Mitigation and the Environment (Wageningen: Wageningen Academic Publishers) pp. 29-62.

Hall, D., P. Hirsch and T.M. Li (2011) Powers of Exclusion: Land Dilemmas in Southeast Asia (Honolulu: University of Hawaii Press).

Lewis, D. and D. Mosse (2006) Development Brokers and Translators: The Ethnography of Aid and Agencies (Bloomfield: Kumarian Press).

Long, N. (2001) Development Sociology: Actor Perspectives (London: Routledge).

Lund, C. (2014) 'Of What is This a Case? Analytical Movements in Qualitative Social Science Research', Human Organization, 73(3), pp. 224-234, DoI: 10.17730/ humo.73.3.e35q482014x033l4.

McCarthy, J., P. Gillespie and Z. Zen (2012) 'Swimming Upstream: Local Indonesian Production Networks in "Globalized" Palm Oil Production', World Development, 40(3) pp. 555-569, DoI: 10.1016/j.worlddev.2011.07.012.

Mitchell, J.C. (2006[1982]) 'Case and Situational Analysis', in Evens, T.M.S. and Don Handelman (eds.) The Manchester School: Practice and Ethnographic Praxis in Anthropology (New York: Berghahn Books) pp. 23-44.

NEDA (National Economic Development Authority) (2010) Updated Medium Term Philippine Development Plan 2004-2010 (Manila: NEDA).

Olivier de Sardan, J-P. (2005) Anthropology and Development: Understanding Contemporary Social Change (London and New York: Zed Books).

Tsing, A. (2005) Friction. An Ethnography of Global Connections (Princeton: Princeton University Press). 
Van Velsen, J. (1967) 'The Extended-Case Method and Situational Analysis', in Epstein, A.L. (ed.) The Craft of Social Anthropology (London: Tavistock) pp. 129-149.

Warsidi, A. (2006) 'GAM Tolak Transmigran Baru Asal Jawa', Tempo Interaktif, 15 March, www.tempo.co/read/news/2006/03/15/05875146/GAM-Tolak-Transmigran-BaruAsal-Jawa (accessed on 12 August 2013). 